\title{
Pengaruh Penyiraman Air Tanah Terhadap Perubahan Sifat Kimia Tanah dan Air Gambut di Kalimantan Tengah
}

\author{
Yulian Taruna ${ }^{1}$, Salampak ${ }^{2}$, Nina Yulianti², Haiki Mart Yupi² ${ }^{2}$, Sustiyah², \\ dan Fahrul Indrajaya ${ }^{2}$ \\ 1)Program Studi Teknik Lingkungan, Pascasarjana Ilmu Lingkungan, Universitas Palangkaraya \\ 2)Fakultas Pertanian, Universitas Palangka Raya, Jalan Yos Sudarso, Palangka Raya \\ Korespondensi: yulian taruna@mining.upr.ac.id
}

\begin{abstract}
This study observed the changes in chemical properties of peat soil and ground water after irrigation of two peat types: inland and transition peat. The research was carried out in the Basic and Analytic Laboratory of Palangka Raya University. Inland peat and water samples were obtained from Palangka Raya City, meanwhile and transitional peatland was taken from Pulang Pisau Regency, Central Kalimantan Province. Research methods consisted of survey and experimental test with complete randomized design (CRD) consisted of groundwater irrigation treatment and was repeated 3 times. The experimental parameters are soil chemical properties such as Ash Content, Base Saturation (KB), Nitrogen (N), Phosphor (P), Exchangeable Potassium (K-dd), Interchangeable Sodium (Na-dd), Interchangeable Calcium (Ca-dd), Interchangeable Magnesium (Mg-dd), Cation Exchange Capacity (CEC), Aluminum Saturation, Iron (Fe), Sulfate $\left(\mathrm{SO}_{4}\right)$, Hydrogen Concentration $(\mathrm{pH})$, and Electrical Delivery Power (EDP), and water chemical properties such as $p H, E D P$, cation, and anions.. The results showed that there has been an increase in the value of $\mathrm{CEC}, \mathrm{P}, \mathrm{Na}-\mathrm{dd}, \mathrm{SO}_{4}, \mathrm{pH}$, and decreased of Ash Content, $\mathrm{N}, \mathrm{K}$-dd, $\mathrm{Ca}$-dd, and EDP on transitional peat soils. Meanwhile, the inland peat soils showed an increase of Ash Content, N, P, Mg-dd, a saturation of Al and $\mathrm{Fe}$, and decreased in the value of $\mathrm{CEC}, \mathrm{Ka}-\mathrm{dd}, \mathrm{Na}-\mathrm{dd}, \mathrm{Ca}-\mathrm{dd}, \mathrm{SO}_{4}, \mathrm{pH}$, and $\mathrm{EDP}$. There were similar effect of groundwater irrigation, towards soil chemical properties, with an exeption of iron levels (Fe). Iron levels $(\mathrm{Fe})$ in transitional peat increase, but decreased in inland peat.
\end{abstract}

Keywords: Palangkaraya peat soil, groundwater, chemical properties, iron levels

\section{PENDAHULUAN}

Lahan gambut terbentuk dari sisa tumbuhan purba yang melalui proses sedimentasi membentuk strata sampai ketebalan $>30 \mathrm{~cm}$ dan mengandung lebih dari $30 \%$ bahan organik. Proses sedimentasi atau penimbunan tersebut merupakan suatu proses yang terjadi secara berkesinambungan dan memerlukan waktu yang lama. Proses ini menyebabkan tumbuhtumbuhan ada yang tenggelam dan mati, sehingga bahan organik terakumulasi (Hardjowigeno, 1996; Barchia, 2006).

Lahan gambut sangat berpotensi sebagai sistem pendukung kehidupan melalui beberapa pelayanan (services) dan fungsi ekologi, ekonomi dan sosial. Perlakuan terhadap lahan gambut harus memperhatikan perlindungan ekosistemnya, sehingga dalam pengelolaan harus berdasarkan zonasi. Terdapat 3 (tiga) zona yaitu core area (area inti), buffer zone (zona penyangga) dan transition area (area transisi), sehingga jika salah dalam pengelolaannya akan berakibat kerusakan lahan gambut serta menyebabkan percepatan hilangnya berbagai potensi keanekaragaman hayati (Jarvie et al, 2003; Galbraith et al, 2005; Egoh et al, 2007; Gunawan et al, 2012).

Tanah gambut digolongkan ke dalam orde Histosol, dengan ketebalan $40 \mathrm{~cm}$ atau lebih yang terletak di atas $80 \mathrm{~cm}$ dari profil tanah (Soil Survey Staff, 1999). Berdasarkan lokasi dan proses terbentuknya, lahan gambut dapat diklasifikasikan menjadi: gambut pantai atau pasang surut, gambut pedalaman, dan gambut peralihan (transisi) (Sukarman, 2006). Fisiografi atau ekosistem lokasi pembentukan gambut sangat mempengaruhi sifat-sifat bawaan gambut, seperti kadar air, kadar serat, kadar C-organik, kadar N, dan sifat kering tidak balik (Riwandi, 2001).

Lahan gambut tropis adalah salah satu sumberdaya alam yang penting dan mempunyai pengaruh kepada lingkungan hidup regional dan global, karena lahan gambut ini merupakan cadangan karbon organik terbesar di dekat permukaan. Pada kondisi yang stabil gambut 
sangat berarti dalam perubahan iklim (Page et al, 2004). Seiring dengan perkembangan pemanfaatan lahannya, lahan gambut di wilayah Kalimantan Tengah saat ini menjadi perhatian serius.

Sebagian besar masyarakat Kalimantan Tengah memanfaatkan lahan gambut sebagai areal usaha tani. Kegiatan pembangunan pertanian di lahan gambut terdiri atas berbagai aktivitas yang meliputi: perubahan peruntukan lahan untuk daerah transmigrasi, pengeringan lahan, dan perkayuan (timber). Hal ini mengakibatkan kestabilan lahan gambut terganggu (Siegert et al, 2001). Kondisi lahan gambut yang kering pada setiap musim kemarau dalam jangka waktu yang relatif lama, berakibat pada kejadian kebakaran lahan. Potensi terjadinya kabakaran lahan gambut juga dipengaruhi oleh keadaan iklim seperti musim kemarau yang ekstrim (El Nino) serta menurunnya permukaan air tanah akibat aktivitas manusia (Wein, 1983; Takahashi et al, 2002).

Di daerah Kalimantan Tengah apabila kedalaman permukaan air tanah lebih besar dari $40 \mathrm{~cm}$, maka kelembaban gambut diatasnya berkurang atau menjadi kering. Kondisi ini sangat berpotensi terjadinya kebakaran. Titik awal kebakaran lahan gambut terjadi pada saat kelembaban gambut (moisture content) $<40 \%$ (Babrauskas, 2003 dalam Hayasaka et al, 2016). Ketebalan gambut juga merupakan faktor yang sangat berpengaruh dalam proses perambatan kebakaran gambut. Ketebalan gambut dapat menjadi faktor utama dalam penentuan lokasi dimana terdapat gambut yang pernah terbakar yang akan berpotensi terbakar kembali pada periode berikutnya (Takahashi et al, 2002). Kebakaran yang terus menerus akan berakibat degradasi pada lahan gambut tersebut.

Lahan gambut yang terdegradasi mengalami penurunan kualitas tanahnya, baik dari sifat kimia, fisika, maupun biologinya (Maftuah et al, 2011; Masganti, 2013; Maftuah et al, 2014). Tanah gambut yang terdegradasi mempunyai nilai $\mathrm{pH}$ yang lebih rendah, kadar P- tersedia dan jumlah unsur-unsur basa serta kadar abu yang lebih rendah (Hartatik dkk., 2011).

Kebakaran lahan gambut akan mempercepat munculnya lapisan tanah mineral yang miskin pada bagian bawah permukaan tanah gambut (Hartatik dkk., 2011) dan bereaksi lebih masam dengan ketersediaan P-nya yang lebih rendah (Masganti dkk., 2002; Masganti, 2003). Hal ini akan menambah daftar permasalahan dalam budidaya tanaman di lahan gambut karena tanaman sulit tumbuh pada kondisi demikian. Jumlah pupuk yang diaplikasikan harus lebih banyak agar pertumbuhan dan produksi tanaman yang tinggi (Masganti 2003). Oleh karena itu, efisiensi dan efektivitas pemupukan menjadi berkurang (Masganti dkk., 2002). Tanah gambut yang terdegradasi juga mempunyai kadar N-total yang lebih rendah. Kebakaran menyebabkan $\mathrm{N}$ dalam tanah juga hilang. Kadar $\mathrm{N}$ yang rendah juga dapat disebabkan oleh rendahnya populasi mikroorganisme dalam tanah gambut yang terdegradasi (Agustina dkk., 2001).

Kekeringan dan kebakaran pada lahan gambut dapat diatasi dengan melakukan penyiraman air pada lahan tersebut dengan tujuan untuk membasahi kembali lahan gambut yang telah kering, dan menjaga tanah gambut tersebut agar tetap lembab. Pembasahan pada lahan gambut yang terbakar mempunyai dampak terhadap sifat fisik, kimia, dan berdampak pada lingkungan maupun kesehatan. Dampak langsung dari pembasahan terhadap lingkungan adalah padamnya api atau sirnanya asap yang mengganggu kesehatan. Penyiraman juga diharapkan dapat mengembalikan kondisi alami gambut dan memperbaiki sifat kimia dan kesuburan tanahnya.

Di musim kemarau, ketersediaan air permukaan berkurang. Sumber air permukaan yang tertampung dalam kolam-kolam, embung, dan mata air menjadi kering. Hal ini menjadi permasalahan utama dalam upaya mencegah kebakaran gambut melalui pembasahan dan penyiraman lahan (Sustiyah dkk., 2020). Salah satu sumber air yang dapat digunakan adalah 
air tanah atau biasa disebut dengan air sumur bor. Penelitian ini bertujuan mengetahui perbedaan sifat kimia tanah gambut dan sifat kimia air tanah setelah dilakukan penyiraman air tanah (sumur) pada kedua jenis tanah gambut (gambut pedalaman dan gambut tansisi) di Kalimantan Tengah.

\section{BAHAN DAN METODE}

\subsection{Tempat dan Waktu Penelitian}

Penelitian dilaksanakan di Laboratorium Dasar dan Analitik Universitas Palangka Raya. Pengambilan sampel tanah gambut dan air tanah dilakukan di lahan gambut pedalaman Kelurahan Kalampangan, Kecamatan Sebangau
Kota Palangka Raya dan gambut transisi dari Dusun Sidodadi, Desa Kanamit Barat, Kecamatan Maliku, Kabupaten Pulang Pisau, Provinsi Kalimantan Tengah. Letak dari lokasi penelitian disajikan pada Gambar 1. Sampel tanah dianalisa di Laboratorium Tanah Balai Penelitian Pertanian Lahan Rawa (Balittra) Kalimantan Selatan.

Kondisi lahan gambut pedalaman tempat pengambilan sampel merupakan daerah yang pernah dibuat drainase untuk kepentingan pemanenan gambut maupun budidaya pertanian. Sedangkan kondisi lahan gambut transisi merupakan lahan perkebunan rakyat (Gambar 2).

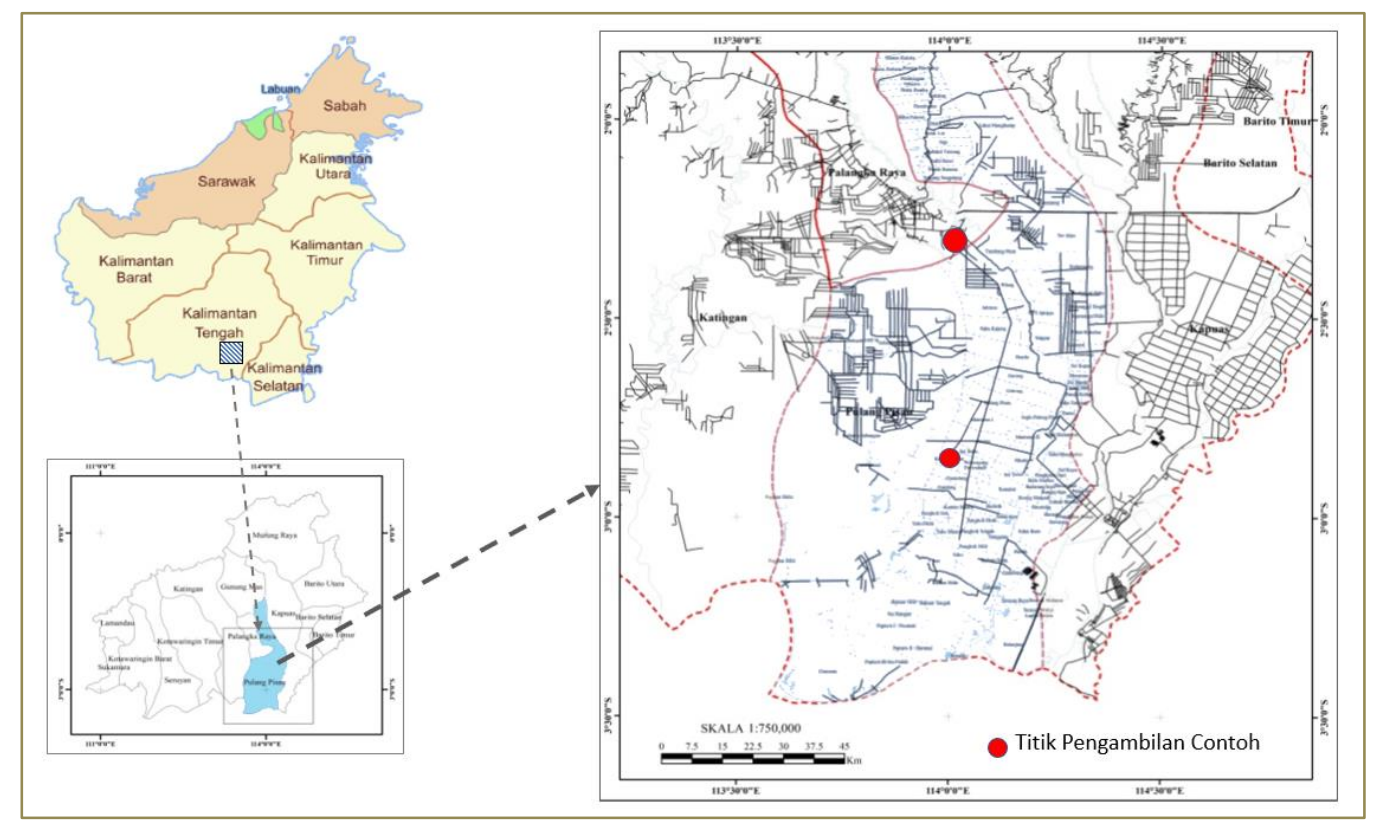

Gambar 1 Peta Lokasi Penelitian

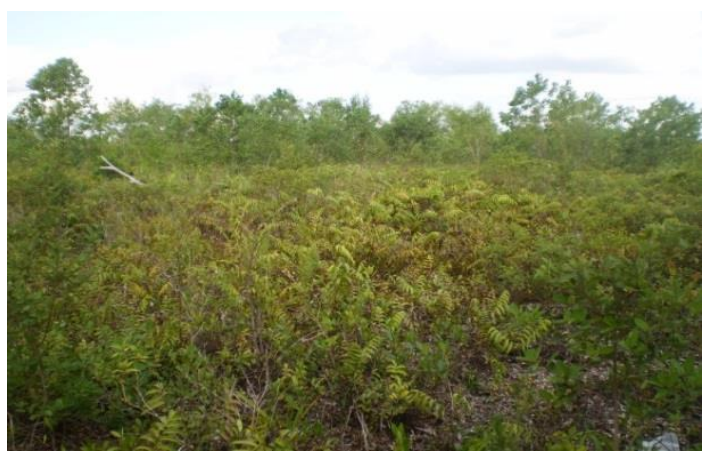

a

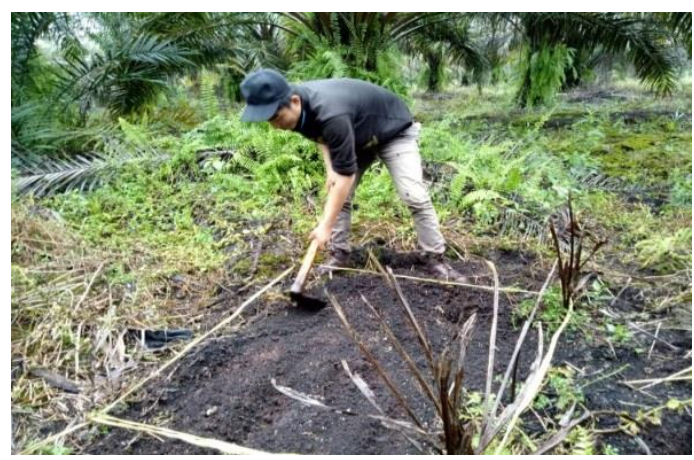

b

Gambar 2 Kondisi titik pengambilan sampel tanah gambut. Gambut pedalaman di Kelurahan Kalampangan, Kecamatan Sebangau (a); Gambut transisi di Desa Kanamit Barat, Kecamatan Maliku (b). 
Penelitian dilakukan kurang lebih 3 (tiga) bulan, yaitu mulai bulan Mei hingga Juli 2019 . Penelitian dilaksanakan pada 2 tahapan, yaitu kegiatan survei lokasi dan penelitian eksprimen. Survei pendahuluan dilakukan untuk menentukan lokasi titik pengambilan sampel tanah gambut yang didasarkan pada letak sumur bor sebagai sumber air tanah. Tahap kedua adalah percobaan eksperimen yang dilaksanakan di laboratorium.

\subsection{Metode Penelitian}

Penelitian eksperimen dilakukan dengan membandingkan hasil perlakuan penyiraman air dari sumur bor atau air tanah yang diberikan pada 2 (dua) jenis tanah gambut yang berbeda yaitu tanah gambut pedalaman dan tanah gambut transisi. Pelaksanaan penelitian ini diawali dengan pengambilan sampel tanah gambut terganggu dan sampel air tanah. Analisis data dilakukan pada contoh tanah dan air untuk memetakan kondisi awal. Tanah dan air yang diambil dari kedua lokasi, kemudian digunakan dalam percobaan eksperimen di laboratorium.

Sampel air tanah diambil dari sumur bor yang telah dikonstruksi sebanyak 10 liter (5 liter untuk analisis sifat kimia air di laboratorium dan 5 liter untuk perlakuan penyiraman). Sampel tanah diambil dengan menggunakan cangkul di 2 (dua) lokasi studi pada 3 (tiga) titik. Jarak 3 (tiga) titik sampel yang diambil adalah $50 \mathrm{~m}, 100 \mathrm{~m}$, dan $150 \mathrm{~m}$ dari titik pengeboran sumur. Pengambilan sampel tanah diambil pada kedalaman 0-20 cm sebagai sampling tanah awal. Sampel tanah awal kemudian dikomposit menjadi 1 (satu) contoh tanah untuk masing-masing lokasi, selanjutnya tanah dikeringanginkan selama 3 (tiga) minggu dan dilakukan analisis sifat kimia tanah di laboratorium.

Penelitian ini merupakan penelitian eksperimen menggunakan motode kolom tanah dengan alat bantu pipa PVC 3 inch (diameter 8,9 $\mathrm{cm}$ ) dengan tinggi pipa $20 \mathrm{~cm}$. Model percobaan menggunakan metode kolom tanah yang terdiri atas 2 kolom pipa (Gambar 3).
Percobaan dilakukan dengan memasukkan sampel tanah terganggu yang telah diambil dari kedalaman $0-20 \mathrm{~cm}$ dengan kematangan gambut saprik yang telah kering angin sebanyak $500 \mathrm{~g}$ per kolom. Masing masing kolom tanah diberi perlakuan penyiraman air dari air sumur bor dengan penambahan air sebanyak $660 \mathrm{ml}-750 \mathrm{ml}$ (setara dengan tanah dalam jenuh air) dengan cara disiram menggunakan gelas ukur $500 \mathrm{ml}$.
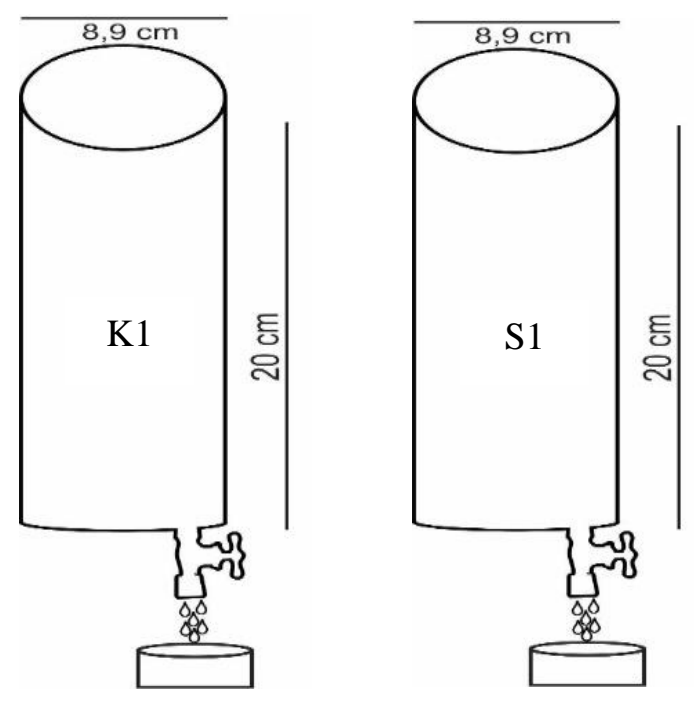

Katerangan :

K1 = Tanah Ds. Kalampangan

S1 = Tanah Dsn. Sidodadi

Gambar 3 Kolom Tanah dari Tabung PVC

Percobaan diulang sebanyak 3 (tiga) kali, sehingga total satuan percobaannya sebanyak 6 (enam) satuan percobaan. Masing-masing satuan percobaan diinkubasi selama 2 bulan. Setelah 1 bulan inkubasi, dilakukan penambahan air sesuai pengurangan selama inkubasi. Setelah 2 bulan diinkubasi, kemudian air dari kolom tanah dikeluarkan secara perlahan dan ditampung. Air yang tertampung kemudian dianalisis sesuai dengan parameter yang dibutuhkan. Tanah yang ada dalam kolom dikeluarkan dan dikompositkan antar masingmasing ulangan per perlakuan untuk dilakukan analisis di laboratorium.

Variabel yang diamati adalah sifat kimia tanah terdiri dari: kadar Abu, Kejenuhan Basa $(\mathrm{KB})$, Nitrogen $(\mathrm{N})$, Posfor (P), Kalium dapat 
ditukar (K-dd), Natrium dapat ditukar (Na-dd), Kalsium dapat ditukar (Ca-dd), Magnesium dapat ditukar (Mg-dd), Kapasitas Tukar Kation (KTK), Kejenuhan Aluminium, Besi (Fe), Sulfat $\left(\mathrm{SO}_{4}\right)$, Konsentrasi Hidrogen $(\mathrm{pH})$, dan Daya Hantar Listrik (DHL). Sifat kimia air yang diamati adalah: $\mathrm{pH}, \mathrm{DHL}$, dan kation serta anion nya (K, Na, $\mathrm{Ca}, \mathrm{Mg}, \mathrm{Fe}, \mathrm{PO}_{4}$ dan $\left.\mathrm{SO}_{4}\right)$. Pengamatan terhadap variable sifat kimia tanah dan sifat kimia air dilakukan di awal dan akhir penelitian.

\subsection{Analisis Data}

Data hasil penelitian diolah dengan membandingkan antara kualitas tanah gambut dan kualitas air tanah pada awal dan akhir percobaan. Pembandingan data juga dilakukan pada kedua jenis gambut (gambut pedalaman dengan gambut transisi). Hasil penelitian disajikan dalam tabulasi data (tabel). Analisis data dilakukan secara deskriptif.

\section{HASIL DAN PEMBAHASAN}

\subsection{Hasil}

\subsubsection{Sifat Kimia Tanah Gambut}

Rerata hasil analisis sifat kimia tanah gambut transisi sebelum (awal) dan sesudah penyiraman air tanah (akhir) dari Dusun Sidodadi disajikan pada Tabel 1. Sifat kimia tanah gambut transisi setelah dilakukan penyiraman menggunakan air tanah mengalami perubahan. Beberapa sifat kimia tanah gambut transisi terjadi peningkatan tetapi ada juga yang mengalami penurunan.

Tabel 1 Rerata Hasil Analisa Sifat Kimia Gambut Transisi Sebelum dan Sesudah Dibasahi Air Tanah

\begin{tabular}{clccrc}
\hline \multirow{2}{*}{ No } & \multirow{2}{*}{ Parameter } & \multirow{2}{*}{ Satuan } & \multicolumn{2}{c}{ Hasil Pengukuran } & \multirow{2}{*}{ Keterangan } \\
\cline { 4 - 5 } & & & Sebelum (awal) & Sesudah (akhir) & \\
\hline 1 & Kadar Abu (\%) & Persen (\%) & 17,87 & 9,92 & turun \\
2 & KTK & $\mathrm{cmol}(+) / \mathrm{Kg}$ & 133,87 & 173,22 & naik \\
3 & Kejenuhan Basa & $(\%)$ & 20,68 & 13,43 & turun \\
4 & N total & $(\%)$ & 0,86 & 1,07 & naik \\
5 & P tersedia & $(\mathrm{ppm})$ & 19,03 & 19,92 & naik \\
6 & K-dd & $\mathrm{cmol}(+) / \mathrm{Kg}$ & 0,23 & 0,14 & turun \\
7 & Na-dd & $\mathrm{cmol}(+) / \mathrm{Kg}$ & 0,24 & 0,36 & naik \\
8 & Ca-dd & $\mathrm{cmol}(+) / \mathrm{Kg}$ & 23,02 & 17,46 & turun \\
9 & Mg-dd & $\mathrm{cmol}(+) / \mathrm{Kg}$ & 4,20 & 5,31 & naik \\
10 & Kejenuhan Al & $\%$ & 10,08 & 22,37 & naik \\
11 & Fe & $\mathrm{ppm}$ & 37,78 & 46,61 & naik \\
12 & $\mathrm{SO}_{4}$ & $\mathrm{ppm}$ & 547,04 & 549,07 & naik \\
13 & $\mathrm{pH}$ & & 3,71 & 4.01 & naik \\
14 & DHL & $\mu S \mathrm{~cm}-1$ & 36,67 & 34,67 & turun \\
\hline
\end{tabular}

Sifat kimia tanah gambut transisi yang mengalami peningkatan adalah: (KTK), N-total, P-tersedia, Na-dd, Mg-dd, Kejenuhan Al, Besi (Fe), Sulfat $\left(\mathrm{SO}_{4}\right)$, dan pH. Sifat kimia tanah gambut transisi yang mengalami penurunan adalah: kadar abu, kejenuhan basa, K-dd, Ca-dd, dan Daya Hantar Listrik (DHL).

Rerata hasil analisis sifat kimia tanah gambut pedalaman sebelum dan sesudah penyiraman dengan airtanah disajikan pada Tabel 2. Sifat kimia tanah gambut pedalaman setelah dilakukan penyiraman menggunakan air tanah mengalami perubahan. Beberapa sifat kimia tanah terjadi peningkatan dan ada juga yang mengalami penurunan. Sifat kimia tanah gambut pedalaman yang mengalami peningkatan adalah: N-total, P-tersedia, Mg-dd, kadar abu, kejenuhan Al, dan Besi (Fe). Sifat kimia tanah gambut pedalaman yang mengalami penurunan adalah: K-dd, Na-dd, Cadd, Sulfat $\left(\mathrm{SO}_{4}\right)$, KTK, $\mathrm{pH}$, dan Daya Hantar Listrik (DHL). 
Tabel 2 Rerata Hasil Analisis Sifat Kimia Gambut Pedalaman Sebelum dan Sesudah Dibasahi Air Tanah

\begin{tabular}{clcccc}
\hline \multirow{2}{*}{ No } & \multirow{2}{*}{ Parameter } & \multirow{2}{*}{ Satuan } & \multicolumn{2}{c}{ Hasil Pengukuran } & \multirow{2}{*}{ Keterangan } \\
\cline { 4 - 5 } & & & Sebelum (awal) & Sesudah (akhir) & \\
\hline 1 & Kadar Abu & Persen (\%) & 2,79 & 21,56 & naik \\
2 & KTK & $\mathrm{cmol}(+) / \mathrm{Kg}$ & 224,86 & 179,36 & turun \\
3 & N total & $(\%)$ & 0,59 & 0,91 & naik \\
4 & P tersedia & $(\%)$ & 25,45 & 28,38 & naik \\
5 & K-dd & $(\mathrm{ppm})$ & 0,41 & 0,22 & turun \\
6 & Na-dd & $\mathrm{cmol}(+) / \mathrm{Kg}$ & 0,47 & 0,30 & turun \\
7 & Ca-dd & $\mathrm{cmol}(+) / \mathrm{Kg}$ & 5,89 & 4,83 & turun \\
8 & Mg-dd & $\mathrm{cmol}(+) / \mathrm{Kg}$ & 5,01 & 6,12 & naik \\
9 & Kejenuhan Al & $\mathrm{cmol}(+) / \mathrm{Kg}$ & 5,53 & 5,97 & naik \\
10 & Fe & $\%$ & 23,32 & 31,29 & naik \\
11 & SO & ppm & 196,48 & 24,29 & turun \\
12 & pH & $\mathrm{ppm}$ & 3,92 & 3,84 & turun \\
13 & DHL & $\mu S \mathrm{~cm}-1$ & 19,00 & 13,33 & turun \\
\hline
\end{tabular}

\subsubsection{Sifat Kimia Air Tanah}

Hasil analisis sifat kimia air tanah sebelum dan sesudah membasahi gambut pada gambut transisi dari Dusun Sidodadi disajikan pada Tabel 3. Berdasarkan hasil analisa pada Tabel 3, sifat kimia air tanah sesudah membasahi gambut transisi mengalami perubahan. Beberapa sifat kimia air tanah terjadi peningkatan dan ada juga yang mengalami penurunan. Sifat kimia air tanah yang mengalami peningkatan adalah: Kalium (K), Natrium (Na), Kalsium (Ca), Magnesium (Mg), Besi ( $\mathrm{Fe})$, Anion Posfot $\left(\mathrm{PO}_{4}\right)$, dan Sulfat $\left(\mathrm{SO}_{4}\right)$. Sifat kimia air tanah yang mengalami penurunan adalah: pH dan Daya Hantar Listrik (DHL).

Tabel 3 Kualitas Air tanah Sebelum dan Sesudah Membasahi Tanah Gambut Transisi

\begin{tabular}{|c|c|c|c|c|c|}
\hline \multirow{2}{*}{ No } & \multirow{2}{*}{ Parameter } & \multirow{2}{*}{ Satuan } & \multicolumn{2}{|c|}{ Hasil Pengukuran } & \multirow{2}{*}{ Keterangan } \\
\hline & & & Sebelum (awal) & Sesudah (akhir) & \\
\hline 1 & $\mathrm{pH}$ & - & 6,16 & 3,76 & turun \\
\hline 2 & DHL & $\mu \mathrm{S} \mathrm{cm}-1$ & 36,00 & 0,27 & turun \\
\hline 3 & $\mathrm{~K}$ & ppm & 3,50 & 8,17 & naik \\
\hline 4 & $\mathrm{Na}$ & ppm & 3,43 & 4,79 & naik \\
\hline 5 & $\mathrm{Ca}$ & ppm & 2,67 & 35,52 & naik \\
\hline 6 & $\mathrm{Mg}$ & ppm & 2,11 & 9,76 & naik \\
\hline 7 & $\mathrm{Fe}$ & ppm & 0,14 & 10,44 & naik \\
\hline 8 & $\mathrm{PO}_{4}$ & ppm & tu & 3,09 & naik \\
\hline 9 & $\mathrm{SO}_{4}$ & ppm & tu & 51,84 & naik \\
\hline
\end{tabular}

Hasil analisis sifat kimia air tanah yang membasahi gambut pedalaman sesudah penyiraman dari Kelurahan Kalampangan disajikan pada Tabel 4. Berdasarkan Tabel 4, sifat kimia air tanah setelah membasahi gambut pedalaman mengalami perubahan. Beberapa sifat kimia air tanah terjadi peningkatan dan ada juga yang mengalami penurunan. Sifat kimia air tanah yang mengalami peningkatan adalah: Kalium (K), Natrium (Na), Kalsium (Ca), Magnesium (Mg), Anion Posfat $\left(\mathrm{PO}_{4}\right)$, dan Sulfat $\left(\mathrm{SO}_{4}\right)$. Sifat kimia air tanah yang mengalami penurunan adalah: pH, Daya Hantar Listrik (DHL), dan (Fe). 
Tabel 4 Kualitas Air tanah Sebelum dan Sesudah Membasahi Tanah Gambut Pedalaman

\begin{tabular}{|c|c|c|c|c|c|}
\hline \multirow{2}{*}{ No } & \multirow{2}{*}{ Parameter } & \multirow{2}{*}{ Satuan } & \multicolumn{2}{|c|}{ Hasil Pengukuran } & \multirow{2}{*}{ Keterangar } \\
\hline & & & Sebelum (awal) & Sesudah (akhir) & \\
\hline 1 & $\mathrm{pH}$ & & 3,93 & 3,54 & turun \\
\hline 2 & DHL & $\mu \mathrm{S} \mathrm{cm} \mathrm{cm}^{-1}$ & 22,66 & 0,20 & turun \\
\hline 3 & $\mathrm{~K}$ & $\mathrm{ppm}$ & 0,75 & 4,62 & naik \\
\hline 4 & $\mathrm{Na}$ & ppm & 0,74 & 8,17 & naik \\
\hline 5 & $\mathrm{Ca}$ & ppm & 1,29 & 11,61 & naik \\
\hline 6 & $\mathrm{Mg}$ & ppm & 0,45 & 7,57 & naik \\
\hline 7 & $\mathrm{Fe}$ & ppm & 2,71 & 0,69 & turun \\
\hline 8 & $\mathrm{PO}_{4}$ & ppm & 1,60 & 27,73 & naik \\
\hline 9 & $\mathrm{SO}_{4}$ & ppm & 31,60 & 97,11 & naik \\
\hline
\end{tabular}

\subsection{Pembahasan}

Hasil penelitian ini menunjukkan bahwa sifat kimia tanah dan air lindi baik pada gambut transisi maupun pedalaman mengalami perubahan setelah dilakukan penyiraman dengan air tanah (air sumur bor). Berdasarkan Tabel 1 dan 2, tanah gambut transisi dan tanah gambut pedalaman di areal studi memiliki tingkat kesuburan rendah, hal ini ditunjukkan oleh kadar abu yang rendah. Kadar abu di gambut transisi $(9.92 \%$ - $17.87 \%)$ dan kadar abu pada gambut pedalaman $(2.79 \%-21.56 \%)$. Gambut dengan kadar abu yang rendah yaitu berkisar antara $2,4-16,9 \%$ yang berarti tingkat kesuburannya rendah (Radjagukguk, 1997).

Kadar abu merupakan salah satu penciri tingkat kesuburan tanah gambut (Kurnain, 2005 dalam Dariah et al, 2014). Rendahnya kadar abu menunjukkan rendahnya kandungan karbon (Masganti dkk, 2014). Hal ini dijelaskan oleh Agus et al (2012), bahwa kadar karbon pada lahan gambut mengalami penurunan yang signifikan karena kebakaran. Penurunan karbon akan menurunkan kadar abu pada tanah gambut tersebut. Kadar abu merupakan sumber unsur-unsur basa pada tanah gambut (Maftuah dkk, 2011; Masganti 2003; Maftuah dkk, 2015). Pada tanah gambut terdegradasi kadar abu dan kejenuhan basa lebih rendah jika dibandingkan dengan gambut alami.

Indikator dari kesuburan gambut dapat dilihat dari nilai $\mathrm{pH}$ yang sangat masam, yakni < 4.5 (PPT, 1983). Bahan organik yang mengalami dekomposisi memiliki gugus reaktif karboksil dan fenol yang berperan sebagai sumber keasaman (Nusantara dkk, 2012). Nilai pH yang rendah (masam) dengan nilai berkisar antara 4,5 - 5.5 (PPT, 1983) akan berakibat pada rendahnya basa-basa $(\mathrm{K}, \mathrm{Ca}, \mathrm{Mg}$, dan $\mathrm{Na}$ ). Rendahnya kandungan kation basa seperti $\mathrm{Ca}$, $\mathrm{Mg}, \mathrm{K}, \mathrm{Na}$, dan kadar abu berkorelasi dengan tingkat kemasaman tanah $(\mathrm{pH})$ (Driessen dan Soepraptohardjo, 1974; Driessen dan Suhardjo, 1976).

Perubahan kadar basa-basa terlihat baik pada gambut transisi maupun pedalaman setelah penyiraman dengan air sumur. Pada lahan gambut transisi terjadi peningkatan Magnesium (Mg) dari 4,20 menjadi 5,31 $(\mathrm{cmol}(+) / \mathrm{Kg})$, hal ini menunjukkan bahwa terdapat penambahan $\mathrm{Mg}$ dari air sumur. Peningkatan kadar Mg juga dapat berasal dari proses dekomposisi bahan organik selama masa inkubasi (Masganti dkk, 2014). Kriteria $\mathrm{pH}$ tanah gambut transisi dan gambut pedalaman sangat masam (< 4.5), mengakibatkan kation $\mathrm{K}, \mathrm{Ca}, \mathrm{Mg}$, dan $\mathrm{Na}$ yang tidak membentuk ikatan koordinasi sehingga akan mudah tercuci (Sustiyah dkk, 2020).

Nilai N-total pada lahan gambut transisi $(1,07 \%)$ dan lahan gambut pedalaman $(0,91 \%)$ tergolong sangat tinggi (PPT, 1983). Nilai $\mathrm{N}$ total tergolong sangat tinggi pada lahan gambut transisi $(0,86 \%)$ dan pada tanah gambut pedalaman $(0,59 \%)$ sebelum diberi perlakuan penyiraman air tanah. Menurut Noor (2001) nilai $\mathrm{N}$ total relatif tinggi yakni berkisar antara $0,3-4,0 \%$ terdapat pada tanah gambut kayu- 
kayuan. Namun, menurut Radjagukguk (2001), $\mathrm{N}$ total yang relatif tinggi, tidak menunjukkan $\mathrm{N}$ tersedia yang tinggi, oleh karena itu dalam tanah gambut hampir selalu kahat Nitrogen.

Meningkatnya P-tersedia pada gambut setelah dilakukan penyiraman menggunakan air sumur bor menunjukan bahwa terjadi penambahan $\mathrm{P}$ dari air sumur. Peningkatan $\mathrm{P}$ tersedia pada tanah gambut pedalaman mencapai 1,60 ppm. Ketersediaan $\mathrm{P}$ dalam tanah gambut yang tidak terdegradasi lebih tinggi, kondisi ini disebabkan karena kadar abu dalam tanah gambut tersebut tinggi jika dibandingkan dengan lahan gambut yang telah terdegradasi. Kadar abu merupakan sumber $\mathrm{P}$ dalam tanah gambut (Masganti 2003; Hartatik dkk, 2011, Masganti dkk, 2014). Menurut Noor (2001) konsentrasi P-tersedia pada tanah gambut relatif beragam, hal ini dapat disebabkan oleh kondisi karakteristik lahan gambut, keragaman vegetasi dapat mempengaruhi $\mathrm{P}$ tersedia. Vegetasi dan aktivitas akar mampu meningkatkan ketersediaan $\mathrm{P}$ dalam tanah. Kandungan Ptersedia juga dipengaruhi oleh proses dekomposisi dan mineralisasi bahan organik yang dapat mempengaruhi pelepasan $\mathrm{P}$ yang terikat oleh kation-kation ( $\mathrm{Al}, \mathrm{Fe}$ dan $\mathrm{Ca}$ ) (Salampak, 1999).

Hasil dari disosiasi hidroksil pada gugus karboksilat atau fenol akan membentuk muatan negatif (Sustiyah dkk, 2020). Muatan negatif adalah gugus yang menentukan KTK, nilai KTK ini dapat tergantung $\mathrm{pH}$ ( $\mathrm{pH}$ dependent charge). Oleh karena itu, jika pH gambut ditingkatkan maka KTK akan meningkat. Namun, tingginya nilai KTK pada tanah gambut tidak menunjukkan bahwa kapasitas untuk mempertukarkan kation tinggi. Peningkatan KTK pada tanah gambut terjadi karena adanya asam organik dalam tanah dengan gugus karboksil $(-\mathrm{COOH})$ dan gugus fenol $(-\mathrm{OH})$. Semakin meningkatnya gugus karboksil dan fenoliknya, maka KTK tanah gambut semakin tinggi (Salampak, 1999).

Peningkatan $\mathrm{Fe}$ pada kedua jenis tanah (pedalaman atau transisi) akibat perlakuan penyiraman dengan sumber air sumur bor menunjukan bahwa terdapat penambahan Fe dari sumber air yang diaplikasikan pada kedua jenis tanah gambut tersebut. Menurut Hartatik (2012) peningkatan Fe sangat dipengaruhi oleh tingginya hidrolisis $\mathrm{Fe}$ dan lepaskan $\mathrm{H}^{+}$dalam jumlah yang relatif besar ke dalam larutan.

Efek pembasahan tampaknya secara signifikan mengurangi DHL pada kedua jenis tanah gambut (pedalaman dan transisi). Keadaan ini menunjukkan bahwa garam di dalam tanah yang terpapar akibat pasang surut atau intrusi air laut mudah dibilas atau dicuci (Noor dkk., 2008). Nilai DHL pada lahan gambut transisi dan gambut pedalaman berhubungan erat dengan keberadaan sulfat dalam tanah. Penurunan DHL dalam tanah dapat menurunkan sulfat tanah. Hal ini selaras dengan pernyataan Sustiyah dkk (2020) bahwa pembasahan pada lahan secara terus menerus dapat menurunkan nilai DHL tanah. Sebagian ion ikut hilang bersamaan saat pembasahan melalui proses pencucian.

\section{KESIMPULAN}

Hasil penelitian menunjukkan bahwa terdapat perubahan sifat kimia tanah gambut setelah dilakukan penyiraman dengan air tanah atau air dari sumur bor baik pada gambut pedalaman maupun gambut transisi. Beberapa sifat kimia tanah gambut transisi yang mengalami peningkatan adalah: Kapasitas Tukar Kation (KTK), Nitrogen (N), Posfor (P) tersedia, Natrium dapat ditukar (Na-dd), Magnesium dapat ditukar (Mg-dd), Kejenuhan Aluminium/Al, Besi $(\mathrm{Fe})$, Sulfat $\left(\mathrm{SO}_{4}\right)$, dan Konsentrasi Hidrogen. Sifat kimia tanah gambut transisi yang mengalami penurunan adalah: Kadar Abu, Kejenuhan Basa, Kalium dapat ditukar (Kdd), Kalsium dapat ditukar (Cadd), dan Daya Hantar Listrik (DHL). Beberapa sifat kimia tanah gambut pedalaman yang mengalami peningkatan adalah: Nitrogen $(\mathrm{N})$, Fosfor (P), Magnesium dapat ditukar (Mg-dd), Kadar Abu, Kejenuhan Aluminium/Al, dan Besi (Fe). Sifat kimia tanah gambut pedalaman yang mengalami penurunan adalah: Kalium dapat 
ditukar (K-dd), Natrium dapat ditukar (Na-dd), Kalsium dapat ditukar (Ca-dd), Sulfat $\left(\mathrm{SO}_{4}\right)$, Kapasitas Tukar Kation (KTK), Konsentrasi Hidrogen $(\mathrm{pH})$, dan Daya Hantar Listrik (DHL). Hampir semua sifat kimia air gambut transisi dan gambut pedalaman memiliki pengaruh yang sama terhadap pemberian air tanah, kecuali kadar Besi (Fe). Kadar Besi (Fe) pada air gambut transisi mengalami peningkatan dari $0.14 \mathrm{ppm}$ menjadi $10.44 \mathrm{ppm}$ dan pada air gambut pedalaman mengalami penurunan dari $2.71 \mathrm{ppm}$ menjadi $0.69 \mathrm{ppm}$.

\section{DAFTAR PUSTAKA}

Agustina, S. E. R., B. M. Rachmawati, dan Sustiyah. 2001. Inventarisasi micoriza vesicular arbuskula (MVA) pada tanah gambut Kalimantan Tengah. J. AgriPeat. 2(2): 46-52.

Agus, F., A. Mulyani, A. Dariah, Wahyunto, Maswar, and E. Susanti. 2012. Peat maturity and thickness for carbon stock estimation. Proceedings, $14^{\text {th }}$ International Peat Congress. Stockholm, 3-8 June 2012. p: 1 - 5

Barchia, M. F. 2006. Gambut. Agroekosistem dan Transformasi Karbon. Gadjah Mada University Press. Yogyakarta.

Driessen, P. M. and Soepraptohardjo. 1974. Organic soil. In: Soil for Agricultural expansion in Indonesia. ATA 106 Bulettin. Soil Reseach Institute Bogor.

Driessen, P.M. and Suhardjo, H. 1976. On the defective grain formation of sawah rice on peat. Soil Res. Inst. Bull. 3: 20 -44 .

Dariah, A. S. Marwanto \& F. Agus. 2014. Rootand peat-based $\mathrm{CO}_{2}$ emissions from oil palm plantations. Mitigation and Adaptation Strategies for Global Change. 19: 831-843.

Egoh, B., M. Roiget, B. Reyers, A. T. Knight, R. M. Cowling, A. S. van Jaatsveld, A. Welz. 2007. Integrating ecosystem services into conservation assesment: a review. J. Ecological Economics. 63: 714-721.

Galbraith, H., P. Amerasinghe \& H. A. Lee. 2005. The Effects of Agricultural Irrigation on Wetland Ecosystems in Developing Countries: A literature review. CA Discussion Paper 1 Colombo, Sri Lanka: Comprehensive Assessment Secre-tariat.

Gunawan, H., S. Kobayashi, K. Mizuno, Y. Kono. 2012. Peat swamp forest types and their regeneration in the Giam Siak Kecil-Bukit Batu Biosphere Reserve, Riau, Indonesia. Mires and Peat (10): $1-17$.

Hardjowigeno, S. 1996. Pengembangan Lahan Gambut untuk Pertanian Suatu Peluang dan Tantangan. Orasi Ilmiah Guru Besar Tetap Ilmu Tanah Fakultas Pertanian. IPB. Bogor.

Hartatik, W., I.G.M. Subiksa, dan A. Dariah. 2011. Sifat kimia dan fisika lahan gambut. Dalam Nurida, N. L., dkk (Eds.). Pengelolaan Lahan Gambut Berkelanjutan. Balai Penelitian Tanah. Bogor. Hal: 45-56.

Hartatik, W. dan Setyorini, D. 2012. Pemanfaatan pupuk organik untuk meningkatkan kesuburan tanah dan kualitas tanaman. Dalam Wigena dkk (Eds.) Prosiding Seminar Nasional Teknologi Pemupukan dan Pemulihan Lahan Terdegradasi. Bogor, 29 - 30 Juni 2012. Hal: 571 582.

Hayasaka, H, H. Takahashi, S.H. Limin, N. Yulianti, \& A. Usup. 2016. Peat fire occurrence. In Osaki, M \& Tsuji, N (Eds). Tropical Peatland Ecosystems. Springer, Tokyo. p: 377395.

Jarvie, H.P., Neal, C., Withers, P.J.A., Robinson, A. and Salter, N., 2003. Nutrient water quality of the Wye catchment, UK: exploring patterns and fluxes using 
the Environment Agency data archives. Hydrology and Earth System Sciences, 7(5): 722-743.

Maftuah, E., A. Maas, A. Syukur, dan B. H. Purwanto. 2011. Potensi bahan amelioran insitu dalam meningkatkan ketersediaan hara. Dalam Ariyanto dkk. (Eds.). Prosiding Kongres Nasional HITI X: Tanah untuk Kehidupan yang Berkualitas. Buku I. Hal: 330- 340.

Maftuah, E., M. Noor, W. Hartatik, dan D. Nursyamsi. 2015. Pengelolaan dan produktivitas lahan gambut untuk berbagai komoditas tanaman. Dalam Agus, F., dkk (Eds.). Lahan Gambut Indonesia Pembentukan, Karakteristik, dan Potensi Mendukung Ketahanan Pangan (Edisi Revisi). IAARD Press. Bogor. Hal: $131-162$.

Masganti. T. Notohadikusumo, A. Maas, dan B. Radjagukguk. 2002. Efektivitas dan pemupukan $\mathrm{P}$ pada tanah gambut. Jurnal Ilmu Tanah dan Lingkungan 3(2):38-48.

Masganti. 2003. Kajian Upaya Meningkatkan Daya Penyediaan Fosfat dalam Gambut Oligotrofik. Disertasi. Program Pascasarjana UGM, Yogyakarta.

Masganti. 2013. Teknologi inovatif pengelolaan lahan suboptimal gambut dan sulfat masam untuk peningkatan produksi tanaman pangan. Jurnal Pengembangan Inovasi Pertanian. 6(4): 187-197.

Masganti, Wahyunto, A. Dariah, Nurhayati, dan R. Yusuf. 2014. Karakteristik dan potensi pemanfaatan lahan gambut terdegradasi di Provinsi Riau. Jurnal Sumberdaya Lahan. 8(1): 59-66.

Noor, M. 2001. Pertanian Lahan Gambut. Potensi dan Kendala. Penerbit Kanisius. Yogyakarta.
Noor. M, A. Maas, T. Notohadikusomo. 2008. Pengaruh pengeringan dan pembasahan terhadap sifat kimia tanah sulfat masam Kalimantan. Jurnal Tanah dan Iklim. 27: 33-44.

Page, S. E., R. A. J. Wüst, D. Weiss, J. O. Rieley, W. Shotyk, \& S. H. Limin. 2004. A record of late Pleistocene and Holocene carbon accumulation and climate change from an equatorial peat bog (Kalimantan, Indonesia): implications for past, present and future carbon dynamics. Journal of Quaternary Science. 19: 625-635.

Pusat Penelitian Tanah.1983. Kriteria Penilaian Data Analisis Sifat Kimia Tanah.

Radjagukguk, B. 1997. Peat soil of Indonesia: location, classification, and problems for sustainability. In Rieley and Page (Eds.). Biodiversity and Sustainability of Tropical Peat and Peatland. Samara Publishing Ltd. Cardigan. UK. p: 45-54.

Radjagukguk B. 2001. Perubahan sifat-sifat fisik dan kimia tanah gambut akibat reklamasi lahan gambut untuk pertanian. Jurnal Ilmu Tanah dan Lingkungan (2).

Riwandi. 2001. Kajian Stabilitas Gambut Tropika Indonesia Berdasarkan Analisis Kehilangan Karbon Organik, Sifat Fisiko Kimia, dan Komposisi Bahan Gambut. Disertasi. Institut Pertanian Bogor.

Nusantara, R. W., Sudarmadji, T. S. Djohan, \& E. Haryono. 2012. Karakteristik fisik lahan akibat alih fungsi lahan hutan rawa gambut. Jurnal Perkebunan dan Lahan Tropika. 2(2): 58-70.

Salampak. 1999. Peningkatan produktivitas tanah gambut yang disawahkan dengan pemberian bahan amelioran tanah mineral berkadar besi tinggi. Disertasi. Institut Pertanian Bogor. Bogor. 
Siegert, F., G. Ruecker, A. Hinrichs, A. A. Hoffmann. 2001. Increased damage from fires inlogged forests during droughts caused by El niño. Nature. 414: 437-440.

Sukarman. 2014. Pembentukan, sebaran dan kesesuaian lahan gambut Indonesia. Dalam Nurida, N. L. dkk (Eds). Panduan Pengelolaan Berkelanjutan Lahan Gambut Terdegradasi. Balai Besar Penelitian dan Pengembangan Sumberdaya Lahan Pertanian. Bogor. Hal: 2 - 15.

Sustiyah. Z. Damanik, \& Masliani. 2020. Pembasahan pada lahan gambut terbakar dengan berbagai sumber air terhadap perubahan sifat kimia tanah. J. Agri Peat. 21 (1): 48-55.

Takahashi, H., B. F. Ibie, A. Usup, Yudha, S. H. Limin. 2002. Annual changes of water balance and a drought index in a tropical peat swamp forest of Central Kalimantan. In Rieley, J. O. et al (Eds.). Peatlans for People: Natural Resource Function and Sustainable Management. Proceedings of the International Symposium on Tropical Peatland. Jakarta, 22-23 August 2001. P: 6367.

Wein, R. W. 1983. The Role of Fire in Northern Circumpolar Ecosystem. John Wiley and Sons. 